\title{
Structural Characterization of $\alpha$-Amino Acid Complexes of Molybdates: a Spectroscopic and DFT Study
}

\author{
Lorenzo Biancalana, ${ }^{a}$ Marco Bortoluzzi, ${ }^{b}$ Claudia Forte, ${ }^{c}$ Fabio Marchetti ${ }^{a,}$ and Guido Pampaloni ${ }^{a, *}$ \\ ${ }^{a}$ University of Pisa, Dipartimento di Chimica e Chimica Industriale, Via Moruzzi 3, I-56124 Pisa, Italy. Tel: +39 0502219219. \\ E-mail: guido.pampaloni@unipi.it.Webpage: http://www.dcci.unipi.it/guido-pampaloni.html. \\ ${ }^{b}$ Ca' Foscari University of Venice, Dipartimento di Scienze Molecolari e Nanosistemi Dorsoduro 2137, I-30123 Venezia, Italy. \\ ${ }^{c}$ Istituto di Chimica dei Composti OrganoMetallici, CNR, Area della Ricerca di Pisa, Via Moruzzi 1, I-56124 Pisa, Italy
}

\section{This submission was created using the RSC Article Template (DO NOT DELETE THIS TEXT) (LINE INCLUDED FOR SPACING ONLY - DO NOT DELETE THIS TEXT)}

The reactions of L-enantiopure $\alpha$-amino acids (aaH) with $\mathrm{Na}_{2} \mathrm{MoO}_{4}$ led to the high-yield isolation of $\mathrm{Mo}(\mathrm{VI})$ complexes of general formula $\mathrm{Mo}_{2} \mathrm{O}_{4}(\mathrm{OH})_{4}(\mathrm{aaH})$. A similar outcome was achieved by using $\left(\mathrm{NH}_{4}\right)_{6} \mathrm{Mo}_{7} \mathrm{O}_{24}$ in the place of $\mathrm{Na}_{2} \mathrm{MoO}_{4}$. Solid-state IR and NMR spectroscopy indicated the presence of $c i s-\mathrm{MoO}_{2}$ units linked by a zwitterionic amino acid ligand, via a bidentate bridging coordination through the carboxylate group. Thus possible dinuclear and polynuclear structures are proposed on the basis of DFT calculations.

\section{Introduction}

Molybdenum is found in living organisms at the active site of several enzymes involved in redox reactions, whose clear understanding is still a big challenge for science. ${ }^{1}$ The main bioavailable form of molybdenum is the tetrahedral molybdate ion, i.e. $\left[\mathrm{MoO}_{4}\right]^{2-}$, which is stable and inert in non-acidic solutions, ${ }^{2}$ and presumed to have played a crucial role in the biological evolution. ${ }^{3}$

The study of the interaction between molybdenum compounds and naturally-occurring molecules in aqueous solution is intended to contribute to the coordination chemistry of $\mathrm{Mo}(\mathrm{VI})$ in water and the related concerns, including the biological ones. ${ }^{4}$

On the other hand, $\alpha$-amino acids are good candidates as potential ligands, indeed their coordination to a variety of metal ions has been extensively investigated. ${ }^{5}$ It is noteworthy that the association of natural, chiral $\alpha$-amino acids with water soluble, biocompatible metal compounds may be a privileged way to obtain potential catalysts for environmentally friendly asymmetric synthesis. ${ }^{6}$

In this framework, the chemistry of a variety of Mo(VI) species with $\alpha$-amino acids in aqueous medium has aroused huge interest. ${ }^{7}$ In particular, a series of studies were carried out on complexation equilibria involving $\left[\mathrm{MoO}_{4}\right]^{2-8}$. Working in mildly acidic conditions $(4.5<\mathrm{pH}<7)$, complex formation was observed for those $\alpha$-amino acids with an ionisable side-chain, however isolation in the solid state was limited to a few cases. ${ }^{9,10}$ On the other hand, the products of the molybdate/ $\alpha$-amino acid interaction could be isolated more favourably at lower $\mathrm{pH}$ values $(\mathrm{pH}=0-2)$. $^{5 \mathrm{a}, 9,11}$

The exploration of this piece of chemistry bears an important drawback: the products are insoluble materials whose crystallographic characterization still remains a hard, not achieved task. As a matter of fact, the reported characterisations relied on limited analytical and spectroscopic (IR) data, and for this reason the structure of the Mooxido backbone and the amino acid coordination mode have not been clearly elucidated hitherto. ${ }^{\text {5a,9,11 }}$

In the light of this preface, we decided to deal with the reactions of molybdates, i.e. $\mathrm{Na}_{2} \mathrm{MoO}_{4}$ and $\left(\mathrm{NH}_{4}\right)_{6} \mathrm{Mo}_{7} \mathrm{O}_{24}$, with a selection of $\alpha$ amino acids (glycine, L-phenylalanine, L-leucine, L-methionine, Lproline and $N, N$-dimethyl-L-phenylalanine), in acidic aqueous solution. We present herein the results of our investigation: a detailed structural characterization of the products has been possible for the first time, based on solid-state spectroscopic techniques (IR and NMR) and DFT calculations.

\section{Results and Discussion}

Molybdenum(VI)-amino acid complexes (1-6, see Scheme 1) were prepared from aqueous solutions of $\alpha$-amino acids (aaH) and a molybdate salt, either $\mathrm{Na}_{2} \mathrm{MoO}_{4}$ or $\left(\mathrm{NH}_{4}\right)_{6} \mathrm{Mo}_{7} \mathrm{O}_{24}$, with $\mathrm{Mo} / \mathrm{aaH}=2: 1$ (equation 1). The resulting mixtures were acidified to $\mathrm{pH}=2$, then the precipitation of neutral colourless solids 1-6 followed in variable times (73-92\% yields). ${ }^{12}$

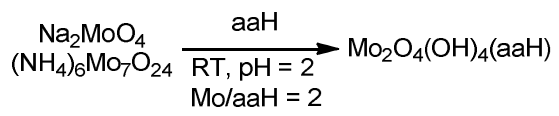

\begin{tabular}{|c|c|}
\hline$\alpha$-amino acid $(\mathrm{aaH})$ & complex $\mathrm{Mo}_{2} \mathrm{O}_{4}(\mathrm{OH})_{4}(\mathrm{aaH})$ \\
\hline Glycine (GlyH) & 1 \\
\hline L-Phenylalanine $(\mathrm{PheH})$ & 2 \\
\hline L-Leucine (LeuH) & 3 \\
\hline L-Methionine (MetH) & 4 \\
\hline L-Proline $($ ProH $)$ & 5 \\
\hline$N, N$-Dimethyl- L-phenylalanine (dmPheH) & 6 \\
\hline
\end{tabular}

Scheme 1 Synthesis of compounds 1-6.

The reactions were investigated on varying the reaction conditions ( $\mathrm{pH}, \mathrm{Mo} / \mathrm{aaH}$ ratio, temperature, nature of molybdate salt and acid; see Supporting Information). As a matter of fact, the formation of 1-6 was generally found to be selective and high yielded. Compounds 1-6 were isolated in good to high yields even by using a large excess of aaH. The synthesis of 1 was effectively performed also at $\mathrm{pH} \mathrm{ca} .0\left(\mathrm{HNO}_{3}\right.$, $\mathrm{Na}_{2} \mathrm{MoO}_{4} \cdot 2 \mathrm{H}_{2} \mathrm{O}$, room temperature) and at $\mathrm{pH}=1(\mathrm{HCl}$, $\left.\left(\mathrm{NH}_{4}\right)_{2} \mathrm{MoO}_{4}, \mathrm{ca} .100^{\circ} \mathrm{C}\right)$, in spite of the $\mathrm{pH}$-dependent equilibria affecting the molybdate ion. ${ }^{2}$ In other terms, the same products were isolated from distinct solutions containing different cations $\left(\mathrm{Na}^{+}\right.$or $\left.\mathrm{NH}_{4}^{+}\right)$and anions $\left(\mathrm{Cl}^{-}\right.$or $\left.\mathrm{NO}_{3}{ }^{-}\right)$; in addition, chlorine was not incorporated in the isolated materials when using $\mathrm{HCl}$. All of these features agree with the idea that 1-6 are neutral species.

In the case of the reaction between $\mathrm{Na}_{2} \mathrm{MoO}_{4}$ and glycine, we carefully monitored the $\mathrm{pH}$ of the reaction solution under different initial conditions (see Supporting Information); our data indicated a stoichiometric $\mathrm{H}^{+}$/Mo ratio of 4 (equation 2). 


$$
4 \mathrm{H}^{+}+2\left[\mathrm{MoO}_{4}\right]^{2-}+\mathrm{GlyH} \rightarrow \mathrm{Mo}_{2} \mathrm{O}_{4}(\mathrm{OH})_{4}(\mathrm{GlyH})
$$

Complexes 1-6, once isolated in the solid state, resulted almost insoluble, both in $\mathrm{H}_{2} \mathrm{O}$ and in $1 \mathrm{M} \mathrm{HNO}_{3}$ or $\mathrm{HCl}$, while a stronger acidic medium (4 $\mathrm{M} \mathrm{HCl}$ or $\mathrm{HNO}_{3}$ ) was generally needed to obtain colourless solutions. Concerning organic solvents, complexes 1-6 did not dissolve in $\mathrm{MeOH}, \mathrm{EtOH}, \mathrm{Me}_{2} \mathrm{CO}$ and $\mathrm{MeCN}$; instead they dissolved into yellow solutions when treated with DMSO.

The generally observed insolubility of 1-6 prompted us to their characterization by means of solid-state techniques.

As described in the following sections, spectroscopic (IR, NMR) and analytical data indicated the general basic structure $\left[\left(\mathrm{MoO}_{2}(\mathrm{OH})\right)_{2}(\mu-\mathrm{OH})_{2}\left(\mu-\mathrm{aaH}-\kappa O, \kappa O^{\prime}\right)\right]$. This outcome has been supported also by DFT calculations and appears independent on the nature of the ammonium group [i.e. primary $(\mathrm{GlyH}, \mathrm{PheH}, \mathrm{LeuH}$, $\mathrm{MetH})$, secondary cyclic $(\mathrm{ProH})$ or tertiary $(\mathrm{dmPheH})]$. The general coordination mode proposed for aaH is shared also by $\mathbf{4}$ despite the additional, potential donor atom (S) contained in MetH.

\section{Solid-state NMR characterisation}

In general, ${ }^{13} \mathrm{C}$ chemical shifts of $\alpha$-amino acids in $\mathrm{D}_{2} \mathrm{O}$ vary with $\mathrm{pH} .{ }^{13}$ More precisely, an upfield shift of ${ }^{13} \mathrm{C}$ resonances has been observed on going from the amino acidate anion $\left(\mathrm{aa}^{-}\right)$to the zwitterion $(\mathrm{aaH})$ and then to the ammonium acid $\left(\mathrm{aaH}_{2}{ }^{+}\right)$. This effect ${ }^{13(\mathrm{~d})}$ is significant for the carboxylic unit and the adjacent carbons; conversely the remaining nuclei, included those belonging to the side-chain and the $N$-substituents, undergo negligible shift. As an example, Figure 1 reports the case of L-Leucine. ${ }^{13(f)}$

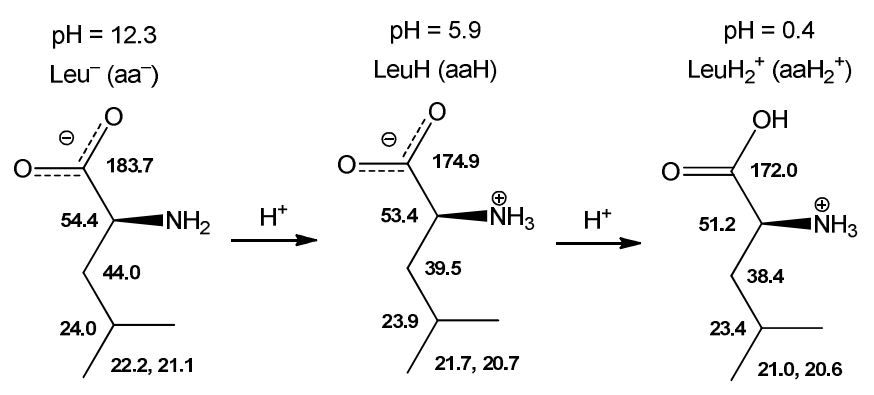

Figure $1{ }^{13} \mathrm{C}$ Chemical shifts at different $\mathrm{pH}$ values for L-leucine in $\mathrm{D}_{2} \mathrm{O} \cdot{ }^{13(f)}$

The solid-state ${ }^{13} \mathrm{C}$ cross polarization with magic angle spinning (CP-MAS) spectra of 1-6 showed one, two or three sets of isotropic resonances attributed to the aaH ligand (see Supporting Information, Table S2). The appearance of more than one signal for a given carbon is presumably due to the presence of different molecular or crystallographic environments. ${ }^{14}$

In addition, we recorded ${ }^{13} \mathrm{C}$ CP-MAS spectra of the $\alpha$-amino acids employed in this work and of their nitrate salts, $\left[\mathrm{aaH}_{2}\right]\left[\mathrm{NO}_{3}\right]$, $\mathrm{aaH}=\mathrm{GlyH}$, PheH, LeuH, MetH. ${ }^{15}$ The latter compounds were obtained as crystalline materials by slow evaporation of the solvent from aqueous solutions containing aaH and $\mathrm{HNO}_{3}$. A comparison of the isotropic ${ }^{13} \mathrm{C}$ chemical shifts related to aaH with the corresponding ones detected for the respective $\left[\mathrm{aaH}_{2}\right]^{+}$species evidenced variations that are analogous to those occurring in $\mathrm{D}_{2} \mathrm{O}$ (see above).

As reported in Table S2, chemical shifts for the carboxylic-, $\alpha$ - and $\beta$-carbons of 1-4 are very close to those found for the corresponding ammonium acid nitrate (i.e., they are deshielded if compared to aaH). The spectrum of $\mathbf{5}$ shows three groups of resonances: one of these follows the general trend observed for $\mathbf{1 - 4}$, while the other two are only slightly shifted with respect to ProH. Chemical shift values for $\mathbf{6}$ are deshielded if compared to $\mathrm{dmPheH}$, with the exception of the $\alpha$ carbon.

It may be concluded that, in general, the coordination of the zwitterionic $\alpha$-amino acid to the metal centre, aaH $\rightarrow$ $\mathrm{Mo}_{2} \mathrm{O}_{4}(\mathrm{OH})_{4}(\mathrm{aaH})$, mimics the electronic effects of protonation, aaH $\rightarrow\left[\mathrm{aaH}_{2}\right]^{+}$. This feature supports the hypothesis that, in 1-6, the $\alpha$ amino acid actually acts as an $\alpha$-ammonium-carboxylate ligand.

\section{Solid-state IR characterisation}

The oxido-molybdenum backbone - The stretching vibrations of $\mathrm{Mo}=\mathrm{O}$ bonds usually give rise to strong and characteristic infrared bands. ${ }^{16}$ In fact the IR spectra of 1-6 showed strong absorptions around 944, 915 and $902 \mathrm{~cm}^{-1}$ (see Supporting Information, Table S3), which are diagnostic for the $c i s-\mathrm{MoO}_{2}$ group. ${ }^{17}$ The presence of three stretching absorptions instead of two [i.e., $v_{\text {sym }}\left(\mathrm{MoO}_{2}\right)$ and $\left.v_{\text {asym }}\left(\mathrm{MoO}_{2}\right)\right]$ might be ascribed to a solid-state effect ${ }^{17(\mathrm{a}, \mathrm{g})}$ or to the fact that more than one $\left\{\mathrm{MoO}_{2}\right\}$ unit is present within a polynuclear complex. ${ }^{18}$ A medium-intensity band around $760 \mathrm{~cm}^{-1}$ has been assigned to the antisymmetric stretching of a bent Mo-O-Mo bridge, ${ }^{16,17(\mathrm{~g}), 18,19}$ while the absorption around $470 \mathrm{~cm}^{-1}$ is presumably due to the corresponding $v_{\text {sym }}\left(\mathrm{Mo}_{2} \mathrm{O}\right) .{ }^{19(\mathrm{a}-\mathrm{b}), 20}$ Moreover, the strong and broad band around $500 \mathrm{~cm}^{-1}$ may be related to other types of bridging oxido groups (e.g. $\left.\mathrm{Mo}_{2}(\mu-\mathrm{O})_{2}\right),{ }^{21,22}$ however $\mathrm{Mo}-\mathrm{O}_{\text {ligand }}$ stretching vibrations may also contribute. ${ }^{17(\mathrm{~g}), 22,23}$

The carboxylate group - The wavenumber difference between the anti-symmetric and the symmetric stretching vibration of a carboxylate ligand $\left(\Delta v_{a-s}\right)$ has proven to be a useful parameter in order to discriminate between monodentate, chelating and bridging-bidentate coordination modes. ${ }^{24}$ More specifically, the separation between carboxylate stretching wavenumbers relative to a reference ionic carboxylate compound; hence $\Delta v_{\mathrm{a}-s}^{\mathrm{rel}}=\Delta v_{a-s}($ metal complex $)-\Delta v_{a-s}$ (ionic reference).

We found a good correlation between $\Delta v^{\text {rel }}{ }_{a-s}$ and the coordination mode of a carboxylate ligand by analyzing the IR data reported for a variety of crystallographically-characterized dioxidomolybdenum(VI) complexes. ${ }^{25}$ Thus $\Delta v^{\text {rel }}$ a-s fall within the range +140 to $+60 \mathrm{~cm}^{-1}$ in the case of monodentate ligands, ${ }^{26}-40$ to $-60 \mathrm{~cm}^{-1}$ for chelating ligands, ${ }^{27}$ and +30 to $-30 \mathrm{~cm}^{-1}$ for bidentate bridging ligands. ${ }^{28,7(\mathrm{~d}-}$ e),21(a) As shown in Table S3, $\Delta v^{\text {rel }} \rightarrow$ values calculated for 1-6 are distributed within the range +33 to $-38 \mathrm{~cm}^{-1}$ (zwitterionic amino acids in the solid state have been taken as ionic references). According to the aforementioned empirical rule, this evidence supports the bidentatebridging coordination of the carboxylate moiety in 1-6.

The ammonium group and other considerations - In the 1400$1600 \mathrm{~cm}^{-1}$ spectral region, the antisymmetric $\delta_{\text {asym }}\left(\mathrm{NH}_{3}^{+}\right)$and symmetric $\delta_{\text {sym }}\left(\mathrm{NH}_{3}{ }^{+}\right)$bands of the ammonium group are recognizable for 1-4. ${ }^{29}$ One deformation band is observed for $\mathbf{5}$, as expected for a secondary ammonium ion. ${ }^{30}$ In the spectrum of $\mathbf{6}$, the $v\left(\mathrm{~N}-\mathrm{CH}_{3}\right)$ has been recognized. ${ }^{31}$ All of these absorptions are slightly shifted with respect to the corresponding, uncoordinated zwitterionic amino acid (see Table S3). In addition, the IR spectra of 1-4 resemble the spectra of the corresponding $\left[\mathrm{aaH}_{2}\right] \mathrm{NO}_{3}$ species, for what regards the $\mathrm{C}-\mathrm{H}$ and $\mathrm{N}-\mathrm{H}$ stretching region $\left(2800-3300 \mathrm{~cm}^{-1}\right),{ }^{32}$ see Figure S7. All of these observations agree with the presence of a protonated ammonium group in compounds 1-6.

The deformation of the $-\mathrm{SCH}_{3}$ group gives rise to another characteristic and intense band, ${ }^{33}$ falling at $1316 \mathrm{~cm}^{-1}$ in the spectrum of MetH and at $1334 \mathrm{~cm}^{-1}$ in the spectrum of its molybdenum complex, 4. A medium intensity absorption at $1333 \mathrm{~cm}^{-1}$ was found in the IR spectra of two structurally determined complexes of $\mathrm{Nb}(\mathrm{V})$ and $\mathrm{Ta}(\mathrm{V})$ bearing a L-methionine ligand bonded to the metal centre 
through the amino and the carboxylate groups. ${ }^{34}$ This suggests that the sulphur atom in $\mathbf{4}$ is not involved in coordination.

\section{Theoretical calculations}

In summary, analytical and spectroscopic characterization of 1-6 highlighted: i) an elemental composition coherent with the empirical formula $\mathrm{Mo}_{2} \mathrm{H}_{4} \mathrm{O}_{8}(\mathrm{aaH})$, ii) the presence of terminal $\left(\right.$ cis- $\left.-\mathrm{MoO}_{2}\right)$ and bridging oxido groups, iii) a bidentate bridging coordination, via the carboxylate group, of the zwitterionic amino acid ligand.

The computational investigation was initially aimed to ascertain possible dinuclear structures for $\mathbf{1}$ and $\mathbf{6}$. The calculated structures were subjected to DFT optimization both in the gas-phase (EDF2 functional) and in the presence of implicit solvation for water (PBE functional with Grimme's corrections for dispersion), using valencedouble- $\zeta$ quality basis sets. The lowest energy structures are shown in Figure 2, while selected bond distances and angles are reported in Table 1. The Cartesian coordinates are given as Supporting Information as a separated .xyz file.
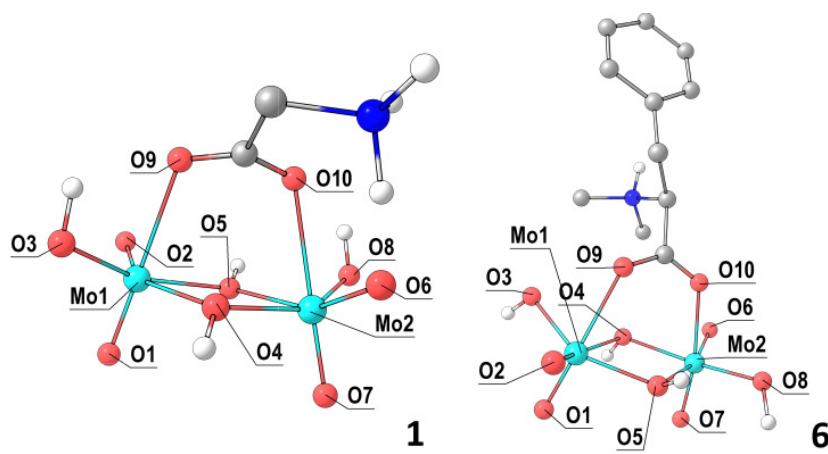

Figure 2 Lowest-energy DFT optimized dinuclear structures of $\mathbf{1}$ and $\mathbf{6}$ (gas-phase EDF2 calculations). White $=$ hydrogen, grey $=$ carbon, blue $=$ nitrogen, red = oxygen, light blue = molybdenum. Carbon-bonded hydrogen atoms have been omitted for clarity.

Table 1 Selected bond distances $(\AA)$ and angles $\left(^{\circ}\right)$ for the dinuclear structures 1 and 6. Data computed using the Grimme-corrected PBE functional in the presence of COSMO solvation model for water. Gas-phase EDF2 data in parentheses.

\begin{tabular}{lll}
\hline Atoms & \multicolumn{1}{c}{$\mathbf{1}$} & $\mathbf{6}$ \\
\hline $\mathrm{Mo}(1)-\mathrm{O}(1)$ & $1.735(1.699)$ & $1.742(1.710)$ \\
$\mathrm{Mo}(2)-\mathrm{O}(7)$ & $1.731(1.691)$ & $1.740(1.707)$ \\
$\mathrm{Mo}(1)-\mathrm{O}(2)$ & $1.743(1.708)$ & $1.740(1.710)$ \\
$\mathrm{Mo}(2)-\mathrm{O}(6)$ & $1.760(1.765)$ & $1.741(1.713)$ \\
$\mathrm{Mo}(1)-\mathrm{O}(4)$ & $2.221(2.263)$ & $2.312(2.323)$ \\
$\mathrm{Mo}(1)-\mathrm{O}(5)$ & $2.096(2.089)$ & $2.072(2.041)$ \\
$\mathrm{Mo}(2)-\mathrm{O}(5)$ & $2.217(2.130)$ & $2.304(2.323)$ \\
$\mathrm{Mo}(2)-\mathrm{O}(4)$ & $2.067(2.050)$ & $2.085(2.098)$ \\
$\mathrm{Mo}(1)-\mathrm{O}(3)$ & $1.942(1.904)$ & $1.954(1.960)$ \\
$\mathrm{Mo}(2)-\mathrm{O}(8)$ & $1.936(1.899)$ & $1.949(1.919)$ \\
$\mathrm{Mo}(1)-\mathrm{O}(9)$ & $2.422(2.572)$ & $2.269(2.310)$ \\
$\mathrm{Mo}(2)-\mathrm{O}(10)$ & $2.385(2.582)$ & $2.298(2.351)$ \\
$\mathrm{O}(1)-\mathrm{Mo}(1)-\mathrm{O}(2)$ & $105.5(105.5)$ & $106.3(105.8)$ \\
$\mathrm{O}(5)-\mathrm{Mo}(1)-\mathrm{O}(9)$ & $85.9(83.1)$ & $77.8(76.5)$ \\
$\mathrm{O}(4)-\mathrm{Mo}(1)-\mathrm{O}(5)$ & $68.1(64.8)$ & $75.5(69.8)$ \\
$\mathrm{O}(4)-\mathrm{Mo}(2)-\mathrm{O}(5)$ & $68.6(67.9)$ & $75.4(70.0)$ \\
\hline
\end{tabular}

Both structures are built up of dinuclear molecules $\left[\left(\mathrm{MoO}_{2}(\mathrm{OH})\right)_{2}(\mu-\mathrm{OH})_{2}\left(\mu-\mathrm{O}_{2} \mathrm{CCHRNHR}_{2}{ }^{-\kappa O}, \kappa \mathrm{O}^{\prime}\right)\right]\left(\mathrm{R}=\mathrm{H}, \mathrm{R}^{\prime}=\mathrm{H}\right.$ for $1, \mathrm{R}=\mathrm{CH}_{2} \mathrm{Ph}, \mathrm{R}^{\prime}=\mathrm{Me}$ for 6 ). Each molybdenum is bonded to two terminal oxido and one terminal hydroxido ligands. The two $\mathrm{MoO}_{2}(\mathrm{OH})$ units are bridged by two hydroxido ligands and the carboxylate group of the $\alpha$-amino acid. Moreover, one bridging $\mathrm{OH}$ ligand and one carboxylic oxygen are trans to a terminal oxido ligand. The coordination spheres around the Mo centres can be described as distorted octahedra, as observable from the $\mathrm{O}_{\text {terminal }}-\mathrm{Mo}-\mathrm{O}_{\text {terminal }}(<$ $\left.85^{\circ}\right)$ and $\mathrm{O}_{\text {bridging }}-\mathrm{Mo}-\mathrm{O}_{\text {bridging }}\left(105^{\circ}\right)$ angles. Both features (trans influence of oxido ligands and distortion from octahedral coordination) are commonly observed in dioxidomolybdenum(VI) complexes. ${ }^{35}$ An intramolecular hydrogen bond involving the ammonium and the nearest $\mathrm{Mo}=\mathrm{O}$ group is present in the dinuclear model for $\mathbf{1}$ while is missing in the analogous for 6: this seems to indicate that intermolecular $\mathrm{N}-\mathrm{H} \cdots \mathrm{O}$ interactions are not essential for the stability of this type of structures.

As discussed above, the DFT-optimised structures of $\mathbf{1}$ and $\mathbf{6}$ are similar to each other : this agrees with the homogeneous spectroscopic data collected, as discussed in the previous sections. Concerning other possible structures, the formal replacement of the bridging hydroxido groups with oxido ligands caused, on theoretical grounds, the dissociation of the carboxylate moiety and/or the migration of one $\mathrm{H}^{+}$ from the ammonium to one oxido. Also the presence of a single bridging ligand, besides the amino acid, was ruled out by DFT calculations, because geometry optimizations of several Mo-O-Mo and $\mathrm{Mo}-\mathrm{OH}-\mathrm{Mo}$ starting structures gave stationary points with two bridging $\mathrm{OH}$ ligands or structures having very high relative energies. Thus the $\mathrm{Mo}_{2}(\mu-\mathrm{OH})_{2}$ core is strongly suggested by theoretical calculations. Moreover, the coordination of water molecules to the $\mathrm{Mo}(\mathrm{VI})$ centres was very weak in all of the cases considered here. The position of the terminal $\mathrm{OH}$ ligands $c i s$ to the carboxylate groups resulted favoured with respect to the trans configuration $(\Delta G=-10.4$ kcal $\mathrm{mol}^{-1}$ for $\mathbf{1},-4.3 \mathrm{kcal} \mathrm{mol}^{-1}$ for $\mathbf{6}$; see the supplementary .xyz file for the 1-trans and 6-trans optimized geometries).

It should be mentioned that a series of X-ray determined molybdates present a structural motif analogous to that proposed for 16: $c i s-\mathrm{MoO}_{2}$ groups bridged by two oxido and one carboxylato unit derived from a zwitterionic ligand LH $(\alpha-, \beta$ - or $\gamma$-amino acids, or nicotinic acid). ${ }^{7 \mathrm{~d}-\mathrm{e}, 21,28}$ In such cases, the resulting dinuclear frames, i.e. $\left[\mathrm{Mo}_{2} \mathrm{O}_{4}(\mu-\mathrm{O})_{2}(\mathrm{LH})\right]$, may condense to three-units rings - in the presence of a central heteroatom such as V(V), Se(IV) or As(III) ${ }^{7 \mathrm{~d}-\mathrm{e}, 28}$ or to infinite oxido-bridged rail-like chains. ${ }^{21}$

Therefore, a theoretical approach was attempted by considering the polymerization of the dinuclear structures (Figure 2). Preliminary DFT calculations indicated the condensation of two terminal $\mathrm{OH}$ groups as the only way to the formation of polymer chains maintaining the dinuclear $\mathrm{Mo}_{2} \mathrm{O}_{4}(\mu-\mathrm{OH})_{2}\left(\mu-\mathrm{aaH}-\kappa O, \kappa O^{\prime}\right)$ core. ${ }^{36}$ In order to restrict the influence of $\mathrm{N}-\mathrm{H} \cdots \mathrm{O}$ hydrogen bonds during the research of the most stable minima, the dinuclear structure optimized for 6 was selected as the starting point. Figure 3 shows the lowest-energy structures for condensation products containing four $(6 \mathbf{T})$, six $(\mathbf{6 H})$ and eight (60) metal centres. Selected ranges of bond distances and angles are reported in Table 2, while the Cartesian coordinates are collected in a separated .xyz file.

Table 2 Selected ranges of bond distances $(\AA)$ and angles $\left(^{\circ}\right)$ for the computed polynuclear structures of 6. PBE/COSMO calculations, EDF2 data in parentheses.

\begin{tabular}{lllc}
\hline Atoms & \multicolumn{1}{c}{$\mathbf{6 T}$} & \multicolumn{1}{c}{$\mathbf{6 H}$} & $\mathbf{6 0}$ \\
\hline $\mathrm{Mo}-\mathrm{O}(\mathrm{a})$ & $1.737-1.747$ & $1.738-1.764$ & $1.738-1.763$ \\
& $(1.708-1.723)$ & $(1.703-1.741)$ & \\
$\mathrm{Mo}-\mathrm{O}(\mathrm{b})$ & $1.942-1.959$ & $1.941-1.952$ & $1.949-1.951$ \\
& $(1.923-1.950)$ & $(1.923-1.956)$ & \\
$\mathrm{Mo}-\mathrm{O}(\mathrm{c})$ & $2.236-2.339$ & $2.257-2.347$ & $2.250-2.358$ \\
& $(2.237-2.401)$ & $(2.268-2.427)$ & \\
& $2.028-2.104$ & $2.017-2.107$ & $2.014-2.125$ \\
& $(2.013-2.099)$ & $(1.979-2.099)$ & \\
$\mathrm{Mo}-\mathrm{O}(\mathrm{d})$ & $1.920-1.925$ & $1.921-1.937$ & $1.912-1.953$ \\
$\mathrm{Mo}-\mathrm{O}(\mathrm{e})$ & $(1.887-1.915)$ & $(1.883-1.955)$ & \\
& $2.247-2.329$ & $2.228-2.327$ & $2.243-2.321$ \\
$\mathrm{O}(\mathrm{c})---\mathrm{O}(\mathrm{c})(\mathrm{H}-\mathrm{bond})$ & $(2.311-2.358)$ & $(2.285-2.345)$ & \\
& 2.571 & $2.548-2.828$ & $2.579-2.719$ \\
& $(2.601)$ & $(2.598-2.724)$ & \\
$\mathrm{O}(\mathrm{a})-\mathrm{Mo}-\mathrm{O}(\mathrm{a})$ & $103.5-106.5$ & $103.5-105.5$ & $103.5-106.7$
\end{tabular}




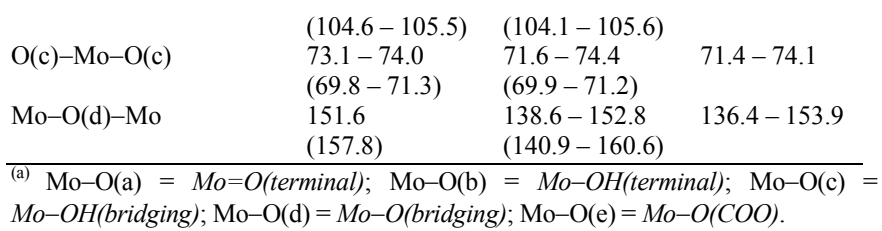

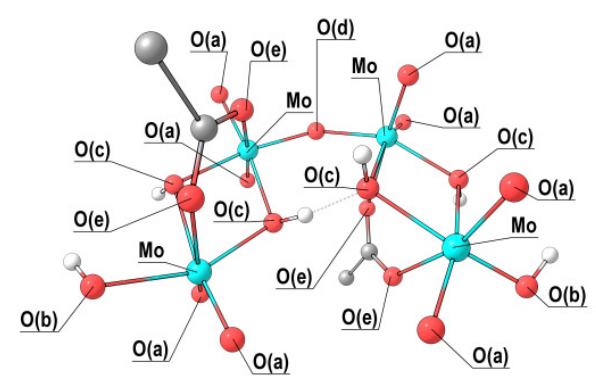

$6 \mathrm{~T}$

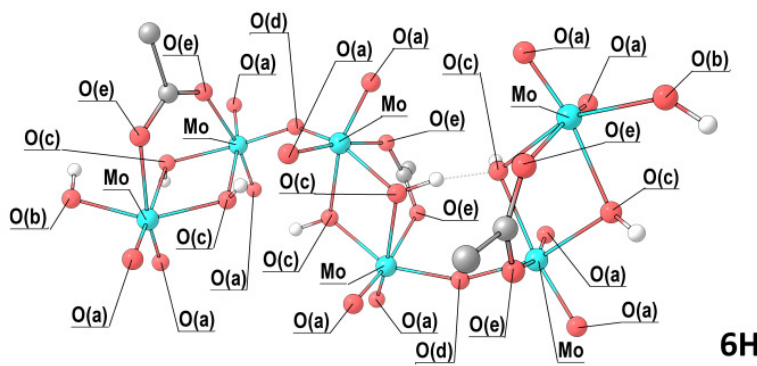

$6 \mathrm{H}$

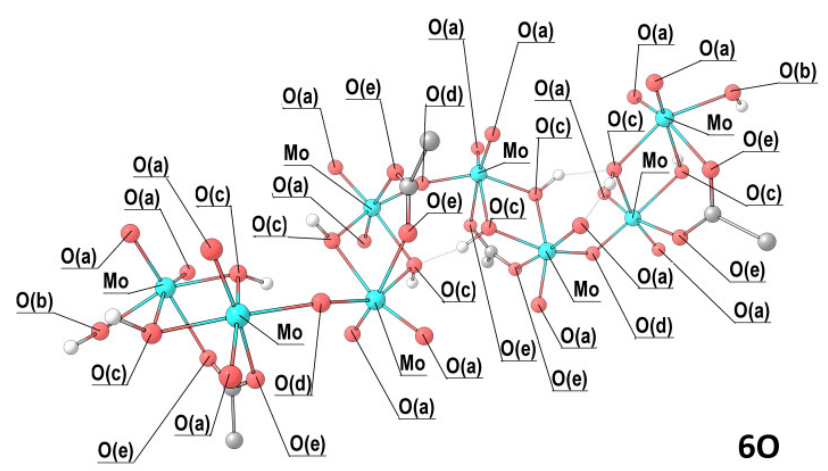

Figure 3 Lowest-energy DFT optimized polynuclear structures of 6 (6T, 6H and 60) $(\mathrm{PBE} / \mathrm{Grimme} / \mathrm{COSMO}$, in the presence of water as implicit solvent). White $=$ hydrogen, grey $=$ carbon, blue $=$ nitrogen, red $=$ oxygen, light blue $=$ molybdenum. The substituents on the carboxylate-bonded carbons have been omitted for clarity.

$\mathrm{Mo}_{2}$ subunits in the polynuclear structures are held together not only by a covalent oxygen bridge, but also by an intramolecular hydrogen bond between two $\mathrm{OH}$ groups, acting as bridging ligands within distinct $\mathrm{Mo}_{2}$ frames. These interactions are sketched in Figure 4 for clarity. The presence of a single bent Mo-O-Mo bridge is supported also by IR characterization (see above).

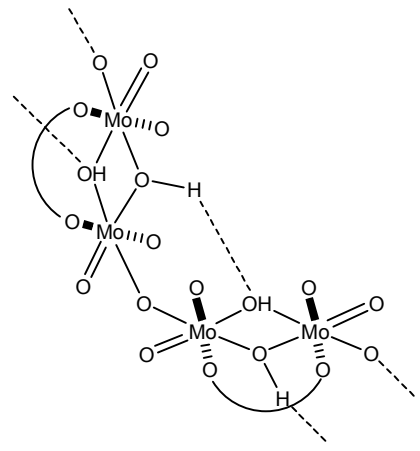

Figure 4 Sketch of the covalent and hydrogen-bond interactions between $\mathrm{Mo}_{2}$ units.

On theoretical grounds, the condensation reactions leading to polynuclear structures (see equation 3 for $\mathrm{aaH}=\mathrm{dmPheH}$ and $\mathrm{n}=1-3$ ) appear thermodynamically favoured, as observable from the $\Delta G$ variations (including solvation) reported in Table 3 for each condensation. This point suggests that 1-6 probably possess, to some extent, a polymeric structure, in accordance with their insolubility in water and in organic solvents. By assuming further condensation reactions between $\mathrm{Mo}_{2}$ subunits $(\mathrm{n}>3)$, an oxido-bridged 2D coordination polymer of general formula $\left\{\mathrm{Mo}_{2} \mathrm{O}_{4}(\mathrm{OH})_{2}(\mathrm{aaH})(\mu\right.$ O) $\}_{n} \cdot \mathrm{H}_{2} \mathrm{O}$ would be obtained.

$$
\begin{array}{r}
\mathrm{HO}-\left\{\mathrm{Mo}_{2} \mathrm{O}_{4}(\mathrm{OH})_{2}(\mathrm{aaH})(\mu-\mathrm{O})\right\}_{\mathrm{n}}-\mathrm{H}+\mathrm{Mo}_{2} \mathrm{O}_{4}(\mathrm{OH})_{4}(\mathrm{aaH}) \rightarrow \\
\mathrm{HO}-\left\{\mathrm{Mo}_{2} \mathrm{O}_{4}(\mathrm{OH})_{2}(\mathrm{aaH})(\mu-\mathrm{O})\right\}_{(\mathrm{n}+1)}-\mathrm{H}+\mathrm{H}_{2} \mathrm{O}
\end{array}
$$

Table 3 Computed $\Delta \mathrm{G}$ variations (including implicit solvation, water as solvent, $298 \mathrm{~K}$ ) for the condensation steps leading from $\mathbf{6}$ to $\mathbf{6 0}$ (PBE/Grimme/COSMO calculations).

\begin{tabular}{cc}
\hline Step & $\mathbf{\Delta G}, \mathbf{~ k c a l} \cdot \mathbf{m o l}^{\mathbf{- 1}}$ \\
\hline $\mathbf{6}+\mathbf{6} \rightarrow \mathbf{6} \mathbf{T}+\mathrm{H}_{2} \mathrm{O}$ & -10.0 \\
$\mathbf{6 T}+\mathbf{6} \rightarrow \mathbf{6 H}+\mathrm{H}_{2} \mathrm{O}$ & -7.1 \\
$\mathbf{6 H}+\mathbf{6} \rightarrow \mathbf{6 0}+\mathrm{H}_{2} \mathrm{O}$ & -4.1 \\
\hline
\end{tabular}

\section{Conclusions}

We have carried out a detailed solid state characterization of Mo(VI) compounds isolated by reactions of molybdate salts with $\alpha$ amino acids in acidic aqueous solutions. The combination of experimental results with DFT calculations has allowed the unprecedented structural identification of the dinuclear core and the coordination mode of the $\alpha$-amino acid. Moreover, the presumable formation of coordination polymers by condensation reactions has been discussed. This paper contributes to clarify the structural features of a series of compounds obtained by a simple reaction, arousing great interest for the implications associated with the nature of the reactants and the use of water as medium (see Introduction).

\section{Experimental}

General: All manipulations were performed in air with common laboratory glassware. Reactions were carried out using deionised water. The following reagents and solvents were used as received: $\mathrm{Na}_{2} \mathrm{MoO}_{4} \cdot 2 \mathrm{H}_{2} \mathrm{O}$, $\left(\mathrm{NH}_{4}\right)_{6} \mathrm{Mo}_{7} \mathrm{O}_{24} \cdot 4 \mathrm{H}_{2} \mathrm{O}, \mathrm{CaH}_{2}$ (Alfa Aesar), glycine (GlyH), L-phenylalanine (PheH), L-leucine (LeuH), L-proline (ProH), L-methionine (MetH), N,Ndimethyl-L-phenylalanine (dmPheH) (Apollo Scientific), $\mathrm{NaOH}, \mathrm{DMSO}$ (Carlo Erba), potassium hydrogen phthalate (Fluka), $\mathrm{MoO}_{2}(\mathrm{acac})_{2}, 65 \%$ $\mathrm{HNO}_{3}, 37 \% \mathrm{HCl}$, methanol, 96\% ethanol, acetone, diethyl ether (SigmaAldrich). $\left(\mathrm{NH}_{4}\right)_{2} \mathrm{MoO}_{4}$ was prepared from $\left(\mathrm{NH}_{4}\right)_{6} \mathrm{Mo}_{7} \mathrm{O}_{24} \cdot 4 \mathrm{H}_{2} \mathrm{O}$ according to the literature. ${ }^{37}$ An Orion $\mathrm{pH}$-meter equipped with a Hamilton glass $\mathrm{pH}$ electrode was used for $\mathrm{pH}$ measurements. The instrument was routinely calibrated with standard $\mathrm{pH}=4.0$ and $\mathrm{pH}=7.0$ buffer solutions (Fluka). Infrared spectra were recorded on a Perkin Elmer FT-IR spectrometer. The UATR sampling accessory was used in the $650-4000 \mathrm{~cm}^{-1}$ range. Spectra in the $360-650 \mathrm{~cm}^{-1}$ region were recorded in the transmission mode on Nujol mulls. NMR solution spectra were recorded on a Bruker Avance DRX-400 instrument equipped with a BBFO broad-band probe. Chemical shifts for ${ }^{1} \mathrm{H}$ and ${ }^{13} \mathrm{C}$ were referenced to tetramethylsilane. CP-MAS NMR spectra were recorded on a Bruker AMX300WB spectrometer working at 75.47 $\mathrm{MHz}$ for carbon, using a CP pulse sequence with a $90^{\circ}$ pulse of $3.4 \mu \mathrm{s}$, a contact time of $2 \mathrm{~ms}$ and a recycle delay of $4 \mathrm{~s} .4 \mathrm{~mm}$ zirconia rotors were used. A $9 \mathrm{kHz}$ spinning speed was used except when, due to the consistency of the sample, homogeneous packing within the rotor was difficult and a 
stable rotation was achieved at a lower spinning speed $(5 \mathrm{kHz})$. Carbonyl and aromatic spinning sidebands were detected at $\pm 119 \mathrm{ppm}$ and $\pm 66 \mathrm{ppm}$ for $9 \mathrm{kHz}$ and $5 \mathrm{kHz}$ rotation, respectively. Spectral editing techniques ${ }^{38}$ were used to aid the spectral assignment in the case of dmPheH and its molybdenum complex. Carbon, hydrogen and nitrogen analyses were performed on a Carlo Erba mod. 1106 instrument. Molybdenum content was determined with the spectrophotometric method proposed by Crouthamel e Johnson ${ }^{39}$ after dissolution of a weighted amount of sample (30-60 mg) in $100 \mathrm{~mL}$ of $4 \mathrm{M} \mathrm{HCl}$. A calibration curve was obtained using $\left(\mathrm{NH}_{4}\right)_{6} \mathrm{Mo}_{7} \mathrm{O}_{24} \cdot 4 \mathrm{H}_{2} \mathrm{O}$ as standard $\left(R^{2}=0.999\right)$, while $\mathrm{MoO}_{2}(\mathrm{acac})_{2}$ was used as a reference compound (Anal. Found: Mo $30.2 \% . \mathrm{C}_{10} \mathrm{H}_{14} \mathrm{MoO}_{4}$ requires Mo $29.8 \%$ ).

Synthesis of $\mathrm{Mo}_{2} \mathrm{O}_{4}(\mathrm{OH})_{4}(\mathbf{a a H})$, 1-6: Compound $\mathrm{Na}_{2} \mathrm{MoO}_{4} \cdot 2 \mathrm{H}_{2} \mathrm{O}$ or $\left(\mathrm{NH}_{4}\right)_{6} \mathrm{Mo}_{7} \mathrm{O}_{24} \cdot 4 \mathrm{H}_{2} \mathrm{O}(4.00 \mathrm{mmol}$ of $\mathrm{Mo})$ and the $\alpha$-amino acid (aaH, 2.00 $\mathrm{mmol})$ were dissolved in water $(30 \mathrm{~mL})$, then $1 \mathrm{M} \mathrm{HNO}_{3}$ was added until $\mathrm{pH}=1.6-2.0$. The resulting pale-yellow solution $\left(c_{\mathrm{Mo}}=0.11 \mathrm{M}\right)$ was stirred at room temperature. A colourless solid (1-6) was obtained in a variable time, depending on the amino acid employed. Then the reaction mixture was filtered (filtrated solution $\mathrm{pH}=2.1-2.5$ ). The solid was washed with acetone, diethyl ether and then dried in vacuo over $\mathrm{CaH}_{2}$. Details for single preparations with $\mathrm{Na}_{2} \mathrm{MoO}_{4} \cdot 2 \mathrm{H}_{2} \mathrm{O}$ are given below; analogous outcomes were obtained by using $\left(\mathrm{NH}_{4}\right)_{6} \mathrm{Mo}_{7} \mathrm{O}_{24} \cdot 4 \mathrm{H}_{2} \mathrm{O}$

$\mathrm{Mo}_{2} \mathrm{O}_{4}(\mathrm{OH})_{4}(\mathbf{G l y H})$, 1: A precipitate formed in 25 minutes $(715 \mathrm{mg}$, 90\%). Anal. Found: C, 6.03; H, 2.13; Mo, 49.1; N, 3.67\%. $\mathrm{C}_{2} \mathrm{H}_{9} \mathrm{Mo}_{2} \mathrm{NO}_{10}$ requires $\mathrm{C}, 6.02 ; \mathrm{H}, 2.27$; Mo, 48.1; N, 3.51\%. ${ }^{40}$ IR (ATR and Nujol): $\tilde{v}_{\max } / \mathrm{cm}^{-1} 3565 \mathrm{w}, 3424 \mathrm{~m}, 3362 \mathrm{~m}, 3225 \mathrm{~m}, 3045 \mathrm{~m}, 3011 \mathrm{~m}, 2926 \mathrm{~m}, 2757 \mathrm{~m}$, $2650 \mathrm{~m}, 1672 \mathrm{w}, 1623 \mathrm{~s}, 1590 \mathrm{~s}, 1512 \mathrm{~s}, 1456 \mathrm{~s}, 1412 \mathrm{~s}, 1340 \mathrm{~s}, 1148 \mathrm{w}, 1118 \mathrm{w}$, 1100w-sh, 946vs, 918vs, 903vs, 761m, 732w-sh, 531vs-br, 473m-sh, 384w. ${ }^{13} \mathrm{C}$ NMR (75.47 MHz, CP-MAS): $\delta /$ ppm $172.0(\mathrm{CO}), 41.3\left(\mathrm{CH}_{2}\right)$.

$\mathrm{Mo}_{2} \mathrm{O}_{4}(\mathbf{O H})_{4}(\mathbf{P h e H}), 2:$ A precipitate formed in 2.5 hours $(805 \mathrm{mg}, 90 \%)$ Anal. Found: C, 22.05; H, 2.85; Mo, 40.1; N, 2.75\%. $\mathrm{C}_{9} \mathrm{H}_{15} \mathrm{Mo}_{2} \mathrm{NO}_{10}$ requires $\mathrm{C}, 22.10 ; \mathrm{H}, 3.09 ; \mathrm{Mo}, 39.2 ; \mathrm{N}, 2.86 \%{ }^{40}$ IR (ATR and Nujol): $\tilde{v}_{\max } / \mathrm{cm}^{-1} 3605 \mathrm{w}-\mathrm{sh}, 3561 \mathrm{w}, 3136 \mathrm{w}-\mathrm{br}, 3033 \mathrm{w}, 2945 \mathrm{w}, 2908 \mathrm{w}, 2831 \mathrm{w}$, $2764 \mathrm{w}, 1607 \mathrm{~s}, 1525 \mathrm{~m}, 1498 \mathrm{~m}-\mathrm{sh}, 1454 \mathrm{~m}, 1426 \mathrm{~s}, 1346 \mathrm{~m}, 1300 \mathrm{w}, 1248 \mathrm{w}$ $1143 \mathrm{w}, 1105 \mathrm{w}, 1084 \mathrm{w}, 942 \mathrm{vs}, 913 \mathrm{vs}-\mathrm{sh}, 904 \mathrm{vs}, 856 \mathrm{w}-\mathrm{sh}, 756 \mathrm{~m}, 738 \mathrm{w}-\mathrm{sh}$, 705w, 534vs-br. ${ }^{13} \mathrm{C}$ NMR (75.47 MHz, CP-MAS): $\delta /$ ppm 172.6 (CO), $134.5(\mathrm{Ph}), 133.6(\mathrm{Ph}), 132.5(\mathrm{Ph}), 129.6(\mathrm{Ph}), 57.3(\mathrm{CH}), 35.6\left(\mathrm{CH}_{2}\right)$.

$\mathrm{Mo}_{2} \mathrm{O}_{4}(\mathrm{OH})_{4}(\mathrm{LeuH})$, 3: No precipitate was observed after 18 hours. Thus the solvent was completely removed in vacuo at $50^{\circ} \mathrm{C}$ affording a paleyellow residue. This residue was washed with water, acetone, diethyl ether and dried in vacuo over $\mathrm{CaH}_{2}$; a colourless solid was obtained $(704 \mathrm{mg}$, $77 \%$ ). Anal. Found: C, 16.15; H, 3.70; Mo, 42.7; N, 3.01\%. $\mathrm{C}_{6} \mathrm{H}_{17} \mathrm{Mo}_{2} \mathrm{NO}_{10}$ requires $\mathrm{C}, 15.83 ; \mathrm{H}, 3.76$; Mo, 42.17; N, 3.08\%. ${ }^{40}$ IR (ATR and Nujol): $\tilde{v}_{\max } / \mathrm{cm}^{-1} 3487 \mathrm{~m}-\mathrm{br}, 3133 \mathrm{~m}-\mathrm{sh}, 3055 \mathrm{~m}, 2956 \mathrm{~m}, 2931 \mathrm{~m}-\mathrm{sh}, 2874 \mathrm{~m}, 1620 \mathrm{~s}-$ sh, 1599s, 1513m, 1506m, 1494m, 1468m, 1428s, 1389m, 1369m, 1350m, $1338 \mathrm{~m}, 1318 \mathrm{~m}, 1293 \mathrm{w}, 1172 \mathrm{w}, 1133 \mathrm{w}, 1123 \mathrm{w}, 939 \mathrm{vs}, 909 \mathrm{vs}-\mathrm{sh}, 896 \mathrm{vs}$, 768w, 750w-sh, 537vs-br, 479s-sh, 380w. ${ }^{13} \mathrm{C}$ NMR $(75.47 \mathrm{MHz}, \mathrm{CP}-$ MAS): $\delta /$ ppm $173.2(\mathrm{CO}), 53.2(\mathrm{CHN}), 39.2\left(\mathrm{CH}_{2}\right), 25.1\left(\mathrm{CHMe}_{2}\right), 21.3$ $\left(\mathrm{CH}_{3}\right), 20.1\left(\mathrm{CH}_{3}\right)$

$\mathrm{Mo}_{2} \mathrm{O}_{4}(\mathrm{OH})_{4}($ MetH), 4: A precipitate formed in 40 minutes $(781 \mathrm{mg}$, $82 \%)$. Anal. Found: C, 12.38; H, 2.99; Mo, 41.5; N, $3.10 \%$ $\mathrm{C}_{5} \mathrm{H}_{15} \mathrm{Mo}_{2} \mathrm{NO}_{10} \mathrm{~S}$ requires C 12.69; H 3.20; Mo 40.56; N 2.96\%. ${ }^{40}$ IR (ATR and Nujol): $\tilde{v}_{\max } / \mathrm{cm}^{-1} 3600 \mathrm{w}-\mathrm{sh}, 3457 \mathrm{w}-\mathrm{br}, 3365 \mathrm{w}-\mathrm{br}, 3143 \mathrm{~m}, 3066 \mathrm{~m}$, 2992 w, 2922m, 2766-2443w, 1603vs, 1575s, 1558m-sh, 1504s, 1440m-sh, $1427 \mathrm{~s}, 1358 \mathrm{~m}, 1334 \mathrm{~s}, 1317 \mathrm{~m}-\mathrm{sh}, 1280 \mathrm{w}, 1252 \mathrm{w}, 1195 \mathrm{w}, 1148 \mathrm{~m}, 1103 \mathrm{w}$, 1073w, 968w-sh, 942vs, 913vs, 894vs, 762m, 748w-sh, 540vs-br, 486m-sh. ${ }^{13} \mathrm{C}$ NMR (75.47 MHz, CP-MAS): $\delta / \mathrm{ppm} 174.4(\mathrm{CO}), 171.8(\mathrm{CO}), 54.7$ $(\mathrm{CH}), 31.5\left(\mathrm{CH}_{2} \mathrm{CH}\right), 30.4\left(\mathrm{CH}_{2} \mathrm{CH}\right), 28.7\left(\mathrm{SCH}_{2}\right), 15.3\left(\mathrm{SCH}_{3}\right), 14.3$ $\left(\mathrm{SCH}_{3}\right), 12.4\left(\mathrm{SCH}_{3}\right)$.

$\mathrm{Mo}_{2} \mathrm{O}_{4}(\mathbf{O H})_{4}(\mathbf{P r o H})$, 5: A precipitate formed in 25 minutes $(642 \mathrm{mg}$, $73 \%$ ). Anal. Found: C, 13.83; H, 2.85; Mo, 44.8; N, 3.25\%. $\mathrm{C}_{5} \mathrm{H}_{13} \mathrm{Mo}_{2} \mathrm{NO}_{10}$ requires $\mathrm{C}, 13.68 ; \mathrm{H}, 2.98 ; \mathrm{Mo}, 43.71 ; \mathrm{N}, 3.19 \%{ }^{40} \mathrm{IR}$ (ATR and Nujol): $\tilde{v}_{\max } / \mathrm{cm}^{-1} 3545 \mathrm{w}-\mathrm{br}, 3157 \mathrm{w}-\mathrm{br}, 3040 \mathrm{w}-\mathrm{br}, 2776 \mathrm{w}, 1603 \mathrm{~s}, 1558 \mathrm{~m}-\mathrm{sh}$, $1472 \mathrm{~m}, 1432 \mathrm{~s}, 1394 \mathrm{~m}, 1372 \mathrm{~m}, 1338 \mathrm{~m}, 1301 \mathrm{w}, 1258 \mathrm{w}, 1175 \mathrm{w}, 944 \mathrm{vs}$ 914vs, 901vs, 767m, 543vs-br, 463m-sh, 389w. ${ }^{13} \mathrm{C}$ NMR $(75.47 \mathrm{MHz}, \mathrm{CP}$ MAS): $\delta /$ ppm $176.8(\mathrm{CO}), 175.2(\mathrm{CO}), 173.5(\mathrm{CO}), 65.0(\mathrm{CH}), 61.0(\mathrm{CH})$, $49.7\left(\mathrm{CH}_{2} \mathrm{~N}\right), 47.3\left(\mathrm{CH}_{2} \mathrm{~N}\right), 46.9\left(\mathrm{CH}_{2} \mathrm{~N}\right), 30.2\left(\mathrm{CH}_{2} \mathrm{CH}\right), 29.4\left(\mathrm{CH}_{2} \mathrm{CH}\right)$, $26.2\left(\mathrm{CH}_{2}\left(\mathrm{CH}_{2}\right)_{2}\right), 25.8\left(\mathrm{CH}_{2}\left(\mathrm{CH}_{2}\right)_{2}\right), 23.7\left(\mathrm{CH}_{2}\left(\mathrm{CH}_{2}\right)_{2}\right)$.

$\mathrm{Mo}_{2} \mathrm{O}_{4}(\mathbf{O H})_{4}(\mathbf{d m P h e H}), 6$ :A precipitate formed immediately $(862 \mathrm{mg}$,
83\%). Anal. Found: C, 26.05; H, 3.55; Mo, 37.5; N, 2.73\%. $\mathrm{C}_{11} \mathrm{H}_{19} \mathrm{Mo}_{2} \mathrm{NO}_{10}$ requires $\mathrm{C}, 25.55 ; \mathrm{H}, 3.70 ; \mathrm{Mo}, 37.11 ; \mathrm{N}, 2.71 \%{ }^{40} \mathrm{IR}$ (ATR and Nujol): $\tilde{v}_{\max } / \mathrm{cm}^{-1} 3563 \mathrm{w}-\mathrm{br}, 3410 \mathrm{w}, 3055 \mathrm{w}, 3040 \mathrm{w}, 3025 \mathrm{w}$, $2965 \mathrm{w}, 2943 \mathrm{w}, 2734 \mathrm{w}, 1626 \mathrm{~s}, 1471 \mathrm{~m}, 1455 \mathrm{~m}, 1432 \mathrm{~m}-\mathrm{sh}, 1495 \mathrm{~m}, 1412 \mathrm{~s}$, $1358 \mathrm{~m}, 1260 \mathrm{w}, 1185 \mathrm{w}, 1170 \mathrm{w}, 1081 \mathrm{w}, 1046 \mathrm{w}, 946 \mathrm{vs}, 916 \mathrm{vs}, 901 \mathrm{vs}-\mathrm{sh}$, 769m, 742m, 705m, 547vs-br, 484m-sh, 438w, 385w. ${ }^{13} \mathrm{C}$ NMR $(75.47$ MHz, CP-MAS): $\delta /$ ppm $171.6(\mathrm{CO}), 140.9(\mathrm{Ph}), 130.8(\mathrm{Ph}), 128.8(\mathrm{Ph})$, $127.8(\mathrm{Ph}), 69.9(\mathrm{CH}), 42.0\left(\mathrm{NCH}_{3}\right), 36.6\left(\mathrm{NCH}_{3}\right), 30.4\left(\mathrm{CH}_{2}\right)$.

Preparation of $\left[\mathbf{a a H}_{2}\right] \mathbf{N O}_{3}, \mathbf{a a H}=\mathbf{G l y H}$, PheH, LeuH, MetH: The $\alpha$ amino acid (2-4 mmol) was dissolved in $1 \mathrm{M} \mathrm{HNO}_{3}(10 \mathrm{~mL}$ for $\mathrm{GlyH}, \mathrm{PheH}$ and LeuH; a stoichiometric amount of $\mathrm{HNO}_{3}$ for MetH) and the resulting colourless solution was allowed to evaporate slowly at room temperature. Colourless crystals of $\left[\mathrm{aaH}_{2}\right] \mathrm{NO}_{3}$ were formed in a period of 5-12 days. These were collected and dried in vacuo over $\mathrm{CaH}_{2}$.

[GlyH $\left.\mathbf{G}_{2}\right] \mathbf{N O}_{3}$ : Anal. Found: C, 17.23; H, 4.11; N, 20.01\%. $\mathrm{C}_{2} \mathrm{H}_{6} \mathrm{~N}_{2} \mathrm{O}_{5}$ requires C, $17.40 ; \mathrm{H}, 4.38 ; \mathrm{N}, 20.29 \%$. IR (ATR): $\tilde{v}_{\max } / \mathrm{cm}^{-1} 3205 \mathrm{~m}, 3150 \mathrm{w}$, $3032 \mathrm{~m}, 2966 \mathrm{~m}, 2909 \mathrm{~m}, 2837 \mathrm{~m}, 2748 \mathrm{w}, 2719 \mathrm{w}, 2640 \mathrm{~m}, 2541 \mathrm{w}, 2442 \mathrm{w}$, $2332 \mathrm{w}, 2262 \mathrm{w}, 2236 \mathrm{w}, 2221 \mathrm{w}, 1986 \mathrm{w}, 1724 \mathrm{~s}, 1627 \mathrm{w}, 1596 \mathrm{w}, 1517 \mathrm{~m}$, $1442 \mathrm{~m}, 1416 \mathrm{~s}, 1355 \mathrm{~s}, 1331 \mathrm{~s}, 1215 \mathrm{~s}, 1124 \mathrm{~s}, 1043 \mathrm{~s}, 914 \mathrm{~s}, 890 \mathrm{~s}, 868 \mathrm{~s}, 813 \mathrm{~s}$, 738m, 712w, 662w. ${ }^{13} \mathrm{C}$ NMR (75.47 MHz, CP-MAS): $\delta /$ ppm 171.7 (CO), $41.1\left(\mathrm{CH}_{2}\right)$.

[PheH $\mathbf{P}_{2} \mathbf{N O}_{3}$ : Anal. Found: C, 47.01; H, 5.11; N, 12.01\%. $\mathrm{C}_{9} \mathrm{H}_{12} \mathrm{~N}_{2} \mathrm{O}_{5}$ requires $\mathrm{C}, 47.37 ; \mathrm{H}, 5.30 ; \mathrm{N}, 12.28 \%$. IR (ATR): $\tilde{v}_{\max } / \mathrm{cm}^{-1} 3148 \mathrm{~m}-\mathrm{br}$, $3026 \mathrm{~m}-\mathrm{br}, 2972 \mathrm{~m}-\mathrm{br}, 1717 \mathrm{~s}, 1667 \mathrm{~m}, 1606 \mathrm{w}, 1584 \mathrm{w}, 1505 \mathrm{~m}, 1496 \mathrm{~m}$, $1471 \mathrm{w}, 1453 \mathrm{~m}, 1445 \mathrm{~m}, 1408 \mathrm{~m}, 1357 \mathrm{~s}, 1335 \mathrm{~s}, 1304 \mathrm{~m}, 1200 \mathrm{~s}, 1150 \mathrm{~m}$, $1119 \mathrm{~m}, 1082 \mathrm{w}, 1045 \mathrm{w}, 1033 \mathrm{w}, 986 \mathrm{w}, 972 \mathrm{w}, 943 \mathrm{w}, 922 \mathrm{w}, 904 \mathrm{w}, 873 \mathrm{w}$, 851w, 814m, 796w, 759w, 743w-sh, 737m, 693s. ${ }^{13} \mathrm{C}$ NMR $(75.47 \mathrm{MHz}$, CP-MAS): $\delta /$ ppm $173.9(\mathrm{CO}), 173.2(\mathrm{CO}), 135.2(\mathrm{Ph}), 132.8(\mathrm{Ph}), 132.3$ $(\mathrm{Ph}), 129.8(\mathrm{Ph}), 129.3(\mathrm{Ph}), 127.6(\mathrm{Ph}), 127.3(\mathrm{Ph}), 56.3(\mathrm{CH}), 55.5(\mathrm{CH})$, $37.0\left(\mathrm{CH}_{2}\right), 36.3\left(\mathrm{CH}_{2}\right)$.

[LeuH ${ }_{2}$ ] $\mathrm{NO}_{3}$ : Anal. Found: C, 37.21; H, 6.99; N, 14.25\%. $\mathrm{C}_{6} \mathrm{H}_{14} \mathrm{~N}_{2} \mathrm{O}_{5}$ requires $\mathrm{C}, 37.11 ; \mathrm{H}, 7.27 ; \mathrm{N}, 14.43 \%$.IR (ATR): $\tilde{v}_{\max } / \mathrm{cm}^{-1} 3221 \mathrm{w}, 3197 \mathrm{w}$, $3149 \mathrm{w}, 2973 \mathrm{~m}, 2958 \mathrm{~m}, 2918 \mathrm{~m}, 2875 \mathrm{~m}, 2768 \mathrm{w}, 2701 \mathrm{w}, 2649 \mathrm{w}, 2583 \mathrm{w}$, $2537 \mathrm{w}, 1717 \mathrm{~s}, 1624 \mathrm{~m}, 1579 \mathrm{w}, 1507 \mathrm{~s}, 1473 \mathrm{w}, 1454 \mathrm{~m}, 1413 \mathrm{~s}, 1386 \mathrm{~s}, 1344 \mathrm{~s}$, $1323 \mathrm{~s}, 1297 \mathrm{~m}, 1212 \mathrm{~s}, 1171 \mathrm{~s}, 1142 \mathrm{~s}, 1075 \mathrm{~m}, 1035 \mathrm{~s}, 995 \mathrm{~m}, 939 \mathrm{~m}, 912 \mathrm{~s}$, 807s, 752w, 730w, 711m. ${ }^{13} \mathrm{C}$ NMR (75.47 MHz, CP-MAS): $\delta /$ ppm 173.9 (CO), $173.1(\mathrm{CO}), 52.9(\mathrm{CHN}), 39.2\left(\mathrm{CH}_{2}\right), 24.7\left(\mathrm{CHMe}_{2}\right), 23.3\left(\mathrm{CH}_{3}\right)$, $22.3\left(\mathrm{CH}_{3}\right), 21.7\left(\mathrm{CH}_{3}\right), 20.0\left(\mathrm{CH}_{3}\right)$.

[MetH $\mathrm{M}_{2} \mathbf{N O}_{3}$ : Anal. Found: C, 27.99; H, 5.46; N, 13.01\%. $\mathrm{C}_{5} \mathrm{H}_{12} \mathrm{~N}_{2} \mathrm{O}_{5} \mathrm{~S}$ requires C, 28.30; H, 5.70; N, 13.20\%. IR (ATR): $\tilde{v}_{\max } / \mathrm{cm}^{-1} 3182 \mathrm{~m}, 3044 \mathrm{~m}$, $2964 \mathrm{~m}, 2921 \mathrm{~m}, 2853 \mathrm{~m}, 2713 \mathrm{w}, 2640 \mathrm{w}, 2604 \mathrm{w}, 1724 \mathrm{~s}, 1620 \mathrm{w}, 1573 \mathrm{w}$, $1506 \mathrm{~m}, 1407 \mathrm{~s}, 1381 \mathrm{~s}, 1340 \mathrm{~s}, 1287 \mathrm{~s}, 1238 \mathrm{~m}, 1225 \mathrm{~m}, 1181 \mathrm{~s}, 1135 \mathrm{~s}, 1100 \mathrm{~m}$ $1073 \mathrm{~m}, 1049 \mathrm{~m}, 1035 \mathrm{~m}, 984 \mathrm{~m}, 948 \mathrm{~m}, 913 \mathrm{~m}, 864 \mathrm{~s}, 817 \mathrm{~m}, 773 \mathrm{~m}, 756 \mathrm{~m}$, 731m, 700m, 655w. ${ }^{13} \mathrm{C}$ NMR (75.47 MHz, CP-MAS): $\delta /$ ppm 173.7 (CO), $172.2(\mathrm{CO}), 54.6(\mathrm{CH}), 54.4(\mathrm{CH}), 32.9\left(\mathrm{CH}_{2} \mathrm{CH}\right), 30.2\left(\mathrm{SCH}_{2}\right), 16.0$ $\left(\mathrm{SCH}_{3}\right), 15.5\left(\mathrm{SCH}_{3}\right)$.

Computational details: The geometry optimization of the complexes was carried out without symmetry constrains, using the hybrid DFT functional $\mathrm{EDF} 2{ }^{41}$ in combination with the split-valence double- $\zeta$ polarized basis set LACVP** $\left(6-31 \mathrm{G}^{* *}\right.$ on the light atoms, LANL2DZ effective core potential on molybdenum centres), ${ }^{42}$ and with the GGA PBE functional combined with an atom-centred doubly numerical polarized basis set. ${ }^{43}$ Dispersion correction was added through the Grimme's approach ${ }^{44}$ and the COSMO implicit solvation model for water was added. ${ }^{45}$ On the basis of the experimentally observed diamagnetism, in all cases the molecules were considered in the singlet state and the "restricted" approach was adopted. IR simulations on the equilibrium geometries were carried out using the harmonic approximation, from which zero-point vibrational energies and thermal corrections to enthalpy and entropy were obtained using standard formulae. ${ }^{46}$ The Cartesian coordinates of the most stable geometries are collected in a separated .xyz file. CINECA is gratefully acknowledged for computational support.

Supporting Information (see footnote on the first page of this article): experimental details; ${ }^{13} \mathrm{C}$ CP-MAS NMR and IR spectra of 1-6 and related $\alpha$-amino acids and $\alpha$-ammonium acid nitrates. The Cartesian coordinates of optimized geometries are collected in a separated .xyz file.

\section{References and Notes}


Current email address: fabmar@dcci.unipi.it.

(a) B. M. Hoffman, D. Lukoyanov, Z.-Y. Yang, D. R. Dean and L. C. Seefeldt, Chem. Rev., 2014, 114, 4041-4062; (b) M. V. Ribbe, Y. Hu, K. O. Hodgson and B. Hedman, Chem. Rev., 2014, 114, 4063-4080; (c) B. M. Hoffman, D. Lukoyanov, D. R. Dean and L. C. Seefeldt, Acc. Chem. Res. 2013, 46, 587-595; (d) T. Spatzal, M. Aksoyoglu, L. Zhang, S. L. A. Andrade, E. Schleicher, S. Weber, D. C. Rees and O. Einsle, Science, 2011, 334, 940; (e) K. M. Lancaster, M. Roemelt, P. Ettenhuber, Y. Hu, M. W. Ribbe, F. Neese, U. Bergmann and S. DeBeer, Science, 2011, 334, 974-977; (f) J. Emsley, in Nature's Building Blocks: an A-Z Guide to the Elements, Oxford University Press, Oxford, 2001; (g) G. C. Tucci, J. P. Donhaue and R. H. Holm, Inorg. Chem., 1998, 37, 1602-1608; (h) R. Hille and H. Sprecher, J. Biol. Chem., 1987, 262, 10914-10917; (i) R. H. Holm and J. M. Berg, Acc. Chem. Res., 1986, 19, 363-370.

2 (a) J. J. Cruywagen, Adv. Inorg. Chem., 2000, 49, 127-182; (b) J. J. Cruywagen, Inorg. Chem., 1980, 19, 552-554.

3 (a) D. Wang, Front. Microbiol. 2012, 3, 1-7; (b) G. Rayner-Canham and J. Grandy, Ed. Chem., 2011, 144-147.

4 (a) D. Collison, C. D. Garner and J. A. Joule, Chem. Soc. Rev., 1996, $25-$ 32; (b) R. Hille, Chem. Rev., 1996, 96, 2757-2816; (c) T. J. Huang and G. P. Haight Jr., J. Am. Chem. Soc., 1970, 92, 2336-2342; (d) J. T. Spence, Coord. Chem. Rev., 1969, 4, 475-498.

5 (a) K. Vassilev, M. Dimitrova, S. Turmanova and R. Milina, Synth. React. Inorg. Metalorg. Nanomet Chem., 2013, 43, 243-249; (b) W. J. Shaw, Catal. Rev. Sci. Engin., 2012, 54, 489-550; (c) D. Desbouis, I. P. Troitsky, M. J. Belousoff, L. Spiccia and B. Graham, Coord. Chem. Rev., 2012, 256, 897-937; (d) K. Micskei, T. Patonay, L. Caglioti and G. Palyi, Chem. Biodiv., 2010, 7, 1660-1669; (e) K. Severin, R. Bergs and W. Beck, Angew. Chem. Int. Ed., 1998, 37, 1635-1654.

6 J. Paradowska, M. Stodulski and J. Mlynarski, Angew. Chem. Int. Ed., 2009, 48, 4288-4297.

7 See for instance: (a) W. S. Zhu, H. Li, Q. Q. Gu, P. Wu, G. Zhu, Y. Yan and G. J. Chen, J.Mol. Catal. A: Chem., 2011, 336, 16-22; (b) M. L. Ramos, L. L. G. Justino and H. D. Barroiws, Dalton Trans., 2011, 40, 4374-4383; (c) E: Cartuyvels, K. Van Hecke, L. Van Meervelt, C. Görller-Walrand and T. N. Parac-Vogt, J. Inorg. Biochem., 2008, 102, 1589-1598; (d) U. Kortz, J. Vaissermann, R. Thouvenot and P. Gouzerh, Inorg. Chem., 2003, 42, 1135-1139; (e) U. Kortz, M. G. Savelieff, F. Y. A. Ghali, L. M. Khalil, S. A. Maalouf and D. I. Sinno, Angew. Chem. Int. Ed., 2002, 41, 4070-4073; (f) J. Lu and Y. Xu, Chem. Mater., 1998, 10, 4141-4147; (g) C. Djordjevic, N. Vuletic, B. A. Jacobs, M. Lee-Renslo and E. Sinn, Inorg. Chem., 1997, 36, 1798-1805; (h) B. Kamenar, B. Korpar-Colig, M. Penavic and M. Cindric, J. Chem. Soc., Dalton Trans., 1990, 1125-1130.

8 Some selected references are: (a) J. J. Cruywagen, J. B. B. Heyns and E. A. Rohwer, J. Chem. Soc., Dalton Trans., 1993, 1713-1717; (b) A. Domènech, E. Llopis, E. Garcia- Eespaña and A. Cervilla, Transition Met. Chem., 1990, 15, 425-428; (c) D. O. Martire, M. R. Feliz and A. L. Capparelli, Polyhedron, 1989, 8, 2225-2232; (d) M. A. Freeman, F. A. Schultz, C. N. Reilley, Inorg. Chem., 1982, 21, 567-576; (e) A. M. V. S. V. Cavaleiro, J. D. Pedrosa de Jesus, V. M. S. Gil, R. D. Gillard, P. A. Williams, Transition Met. Chem., 1982, 7, 75-79.

9 A. Kay and P. C. Mitchell, J. Chem. Soc. A, 1970, 2421-2428.

10 R. J. Butcher, H. K. J. Powell, C. J. Wilkins and S. H. Yong, J. Chem. Soc., Dalton Trans., 1976, 356-359.

11 (a) M. Castillo and P. Palma, Synth. React. Inorg. Met.-Org. Chem., 1984, 14, 1173-1182; (b) K. S. Nagaraja and M. R. Udupa, Indian J. Chem. A, 1983, 22, 531-532; (c) H. Eguchi, T. Takeuchi, A. Ouchi and A. Furuhashi, Bull. Chem. Soc. Jpn., 1969, 42, 3585-3588.

12 As explained later in the text, the proposed structure for 1-6 corresponds to the dinuclear complex $\left[\left(\mathrm{MoO}_{2}(\mathrm{OH})\right)_{2}(\mu-\mathrm{OH})_{2}\left(\mu-\mathrm{aaH}-\kappa O, \kappa O^{\prime}\right)\right]$, which may give rise to an oxido-bridged polymer though the condensation of terminal $-\mathrm{OH}$ ligands. The shortened formula $\mathrm{Mo}_{2} \mathrm{O}_{4}(\mathrm{OH})_{4}(\mathrm{aaH})$ will be used throughout this paper and the Supporting Information.

13 (a) H. L. Surprenant, J. E. Sarneski, R. R. Key, J. T. Byrd and C. N. Reilley, J. Magn. Reson., 1980, 40, 231-243; (b) J. G. Batchelor, J. Feeney and G. C. K. Roberts, J. Magn. Reson., 1975, 20, 19-38; (c) A. R. Quirt, J. R. Lyerla, I. R. Peat Jr., J. S. Cohen, W. F. Reynolds and M. H. Freedman, J. Am. Chem. Soc., 1974, 96, 570-574; (d) M. Christl and J. D.
Roberts, J. Am. Chem. Soc., 1972, 94, 4565-4573; (e) G. Jung, M. Ottnad, W. Voelter and E. Breitmaier, Fresen. Zeit. Anal. Chem., 1972, 261, 328332; (f) F. R. Gurd, P. J. Lawson, D. W. Cochran and E. Wenkert, J. Biol. Chem., 1971, 246, 3725-3730.

14 G. R. Hays, J. Chem. Soc., Perkin Trans. 2, 1983, 1049-1052.

15 (a) S. Asath Bahadur, R. K. Rajaram, M. Nethaji and S. Z. Natarajan, Z. Kristallogr., 2010, 203, 93-100; (b) F. Berrah, N. Benali-Cherif and H. Lamraoui, Acta Crystallogr. Sect. E.-Struct Rep. Online, 2005, 61, o1517o1519; (c) S. Pandiarajan, B. Sridhar and R. K. Rajaram, Acta Crystallogr. Sect. E.-Struct Rep. Online, 2002, 58, o882-o884; (d) B. Sridhar, N. Srinivasan and R. K. Rajaram, Acta Crystallogr. Sect. E. Struct Rep. Online, 2002, 58, o1103-o1105; (e) P. Narayanan and S. Venkataraman, J. Cryst. Mol. Struct., 1975, 5, 15-26.

16 (a) L. Favero, F. Marchetti, G. Pampaloni and S. Zacchini, Dalton Trans., 2014, 43, 495-504; (b) F. Marchetti, G. Pampaloni and S. Zacchini, Dalton Trans., 2013, 42, 15226-15234; (c) F. Marchetti, G. Pampaloni and S. Zacchini, Dalton Trans., 2013, 42, 2477-2487; (d) S. Dolci, F. Marchetti, G. Pampaloni and S. Zacchini, Eur. J. Inorg. Chem., 2013, 42, 1371-1380; (e) W. P. Griffith, J. Chem. Soc. A, 1969, 211-218.

17 (a) X. Ma, K. Starke, C. Schulzke, H.-G. Schmidt and M. Noltemeyer, Eur. J. Inorg. Chem., 2006, 628-637; (b) M. J. Taylor, C. E. F. Rickard and L. A. Kloo, J. Chem. Soc., Dalton Trans., 1998, 3195-3198; (c) B. Kojic-Prodic, Z. Ruzic-Toros, D. Grdenic and L. Golic, Acta Crystallogr. Sect. B-Struct. Sci., 1974, 30, 300-305; (d) B. Kamenar, B. M. Penavic and C. K. Prout, Cryst. Struct. Commun., 1973, 2, 41-44; (e) L. O. Atovmyan and Y. A. Sokolova, Zh. Struk. Khim., 1971, 12, 851-858; (f) B. M. Craven, K. C. Ramey and W. B. Wise, Inorg. Chem., 1971, 10, 2626-2628; (g) R. H. Fenn, J. Chem. Soc. A, 1969, 1764-1769; (h) W. P. Griffith and T. D. Wickins, J. Chem. Soc. A, 1968, 400-404; (i) L. R. Florian and E. R. Corey, Inorg. Chem., 1968, 7, 722-725; (j) F. W. Moore and R. E. Rice, Inorg. Chem., 1968, 7, 2510-2514; (k) M. Cousins and M. L. H. Green, J. Chem. Soc., 1964, 1567-1572.

18 For example, $\mathrm{K}_{2}\left[\mathrm{HMo}_{6} \mathrm{VO}_{22}\left(\mathrm{NH}_{3} \mathrm{CH}_{2} \mathrm{COO}\right)_{3}\right]+8 \mathrm{H}_{2} \mathrm{O}$ is a structurally determined compound with dinuclear $\left(\mathrm{MoO}_{2}\right)_{2}(\mu-\mathrm{O})_{2}$ units and three absorptions at 940,926 and $891 \mathrm{~cm}^{-1}$ are reported for $\mathrm{MoO}_{2}$ stretchings in M. Cindric, N. Strukan, T. Kajfez, G. Giester and B. Kamenar, Inorg. Chem. Comm., 2000, 3, 281-284

19 (a) J. Zhang, Y. Guo, W. Lu, X. Guo, M. Xu and H. Guo, J. Ind. Eng. Chem., 2012, 18, 1824-1827; (b) A. C. Coelho, M. Nolasco, S. S. Balula, M. M. Antunes, C. C. L. Pereira, F. A. Almeida Paz, A A. Valente, M. Pillinger, P; Ribeiro-Claro, J. Klinowski and L. S. Gonçalves, Inorg. Chem., 2011, 50, 525-538; (c) R. Aguado, J. Escribano, M. R. Pedrosa, A. De Cian, R. Sanz and F. J. Arnáiz, Polyhedron, 2007, 26, 3842-3848; (d) B.-Z. Lin and P.-D. Liu, J. Mol. Struct., 2003, 654, 55-60; (e) D. J. Hewkin and W. P. Griffith, J. Chem. Soc. A, 1966, 472-475.

20 R. M. Wing, K. P. Callahan, Inorg. Chem., 1969, 8, 871-874.

21 (a) S.-M. Chen, C.-Z. Lu, Y.-Q. Yu, Q.-Z. Zhang and X. He, Acta Crystallogr. Sect. C-Cryst. Struct. Commun., 2004, 60, m437-m439; (b) T. Yamase, M. Inoue, H. Naruke and K. Fukaya, Chem. Lett., 1999, 7 , 563-564.

22 K. Wieghardt, W. Holzbach and J. Weiss, Inorg. Chem., 1981, 20, $3436-$ 3439 .

23 C. Knobler, B. R. Penfold,.W. T. Robinson, C. J. Wilkins and S. H. Yong, J. Chem. Soc., Dalton Trans., 1980, 248-252.

24 (a) G. B. Deacon and R. J. Phillips, Coord. Chem. Rev., 1980, 33, 227 250; (b) S. D. Robinson and M. F. Uttley, J. Chem. Soc., Dalton Trans., 1973, 1912-1920; (c) K. Nakamoto, J. Fujita, S.; Tanaka and M. Kobayashi, J. Am. Chem. Soc., 1957, 79, 4904-4908.

25 Following Philips and Deacon's method, ${ }^{24(\mathrm{a})}$ we compared the $\Delta v_{a-s}$ values of structurally-determined $\mathrm{Mo}(\mathrm{VI})$-carboxylate complexes with the corresponding values given for respective reference carboxylate compounds. Sodium carboxylates have been generally used for this purpose $^{25(a)}$ except for amino acid complexes. In this case, due to the zwitterionic structure adopted in the solid state, the amino acid itself was taken as reference (e.g. $\Delta v_{a-s}=165 \mathrm{~cm}^{-1}$ for methionine and $\Delta v_{a-s}=162$ $\mathrm{cm}^{-1}$ for sodium methioninate). ${ }^{25(\mathrm{~b})}$ (a) T. H., K. Yamaji, K. M. Yanagisawa, O. Yamamoto, N. Wasada, K. Someno,S. Kinugasa, K. Tanabe, T. Tamura, J. Hiraishi and T. T. Saito, Spectral Database for Organic Compounds, http://sdbs.db.aist.go.jp/sdbs/cgi-bin/cre_index.cgi; 
(b) C. A. Mcauliffe, J, V. Quagliano and L. M. Vallarino, Inorg. Chem., 1966, 5, 1996-2003.

26 (a) B. Modec, D. Dolenc and M. Kasunic, Inorg. Chem., 2008, 47, 3625 3633; (b) E. Cartuyvels, K. Van Hecke, L. Van Meervelt, C. GörllerWalrand and T. N. Parac-Vogt, J. Inorg. Biochem., 2008, 102, 1589-1598; (c) M. Cindric, T. K. Novak, S. Kraljevic, M. Kralj and B. Kamenar, Inorg. Chim. Acta, 2006, 359, 1673-1680; (d) Z.-H. Zhou, S.-Y. Hou, Z.X. Cao, H.-L. Wan and S.-W. Ng, J. Inorg. Biochem., 2004, 98, $1037-$ 1044; (e) Z.-H. Zhou, H. Zhao and K.-R. Tsai, J. Inorg. Biochem., 2004 98, 1787-1794; (f) C. F. Edwards, W. P. Griffith, A. J. P. White and D. J. Williams, J. Chem. Soc., Dalton Trans., 1993, 3813-3819.

27 (a) N. Gharah, B. Chattopadhyay, S. K. Maiti and M. Mukherjee, Trans. Met. Chem., 2010, 35, 531-539; (b) S. K. Maiti, K. M. A. Malik, S. Gupta, S. Chakraborty, A. K. Ganguli, A. K. Mukherjee and R. Bhattacharyya, Inorg. Chem., 2006, 45, 9843-9857; (c) B. Korpar-Colig, M. Cindric, D. Matkovic-Calogovic, V. Vrdoljak and B. Kamenar, Polyhedron, 2002, 21, 147-153.

28 M. Cindric, N. Strukan, M. Devcic and B. Kamenar, Inorg. Chem. Commun., 1999, 2, 558-560.

29 P. J. Stone, J. C. Craig and H. W. Thompson, J. Chem. Soc., 1958, 52-54.

30 R. A. Heacock and L. Marion, Can. J. Chem., 1956, 34, 1782-1795.

31 C. C. Watson, Spectrochim. Acta, 1960, 16, 1322-1327.

32 T. Shimanouchi, Table of Molecular Vibrational Frequencies, Vol. 1, U.S. National Standards Reference Data System, 1972.

33 B. B. Koleva, Vibrational Spectrosc., 2007, 44, 30-35.

34 M. Hayatifar, F. Marchetti, G. Pampaloni and S. Zacchini, Inorg. Chem. 2013, 52, 4017-4025.

35 (a) R. J. Butcher, B. R. Penfold and E. Sinn, J. Chem. Soc. Dalton Trans. 1979, 668-675; (b) E. I. Stiefel, Prog. Inorg. Chem., 1977, 22, 1-223; (c) R. H. Fenn, J. Chem. Soc. A, 1969, 1764-1769.

36 The condensation of two Mo-OH groups leads to the formation of a Mo-O-Mo bridge and does not involve a $\mathrm{pH}$ change: $2 \mathrm{Mo}-\mathrm{OH} \rightarrow \mathrm{Mo}-\mathrm{O}-\mathrm{Mo}+\mathrm{H}_{2} \mathrm{O}$

Hence the stoichiometric ratio $\mathrm{H}^{+} / \mathrm{Mo}=4$ required for the formation of $\mathrm{Mo}_{2} \mathrm{O}_{4}(\mathrm{OH})_{4}(\mathrm{aaH})$ (see above) is not affected by successive condensation reactions leading to $\left\{\mathrm{Mo}_{2} \mathrm{O}_{4}(\mathrm{OH})_{2}(\mu-\mathrm{O})(\mathrm{aaH})\right\}_{\mathrm{n}}$.

37 M. Dittmann and E. Schweda, Z. Anorg. Allg. Chem., 1998, 624, 2033 2037.

38 (a) J. Z. Hu, J. K. Harper, C. Taylor, R. J. Pugmire and D. M. Grant, J. Magn. Reson., 2000, 142, 326-330; (b) X. Wu, S. T. Burns, K. W. Zilm, J. Magn. Reson. A, 1994, 111, 29-36.

39 C. E. Crouthamel and C. E. Johnson, Anal. Chem., 1954, 26, 1284-1291.

40 Calculated values refer to the formula $\mathrm{Mo}_{2} \mathrm{O}_{4}(\mathrm{OH})_{4}(\mathrm{aaH})$, where aaH $=$ amino acid. The corresponding exeperimental results are generally lower for $\mathrm{H}$ and higher for Mo, $\mathrm{N}$ and $\mathrm{C}$, respectively. This can be explained by the formation of $\left\{\mathrm{Mo}_{2} \mathrm{O}_{4}(\mathrm{OH})_{2}(\mathrm{aaH})(\mu-\mathrm{O})\right\}_{\mathrm{n}}$ species via water loss (see equation 3 ).

41 C. Y. Lin, M. W. George and P. M. W. Gill, Aust. J. Chem., 2004, 57, 365-370.

42 (a) M. Dolg, in Modern Methods and Algorithms of Quantum Chemistry (Eds.: J. Grotendorst), John Neumann Institute for Computing, NIC series, Jülich, 2000, pp. 479-508; (b) P. J. Hay and W. R. Wadt, J. Chem. Phys., 1985, 82, 299-310; (c) P. J. Hay, W. R. Wadt, J. Chem. Phys., 1985, 82, 270-283; (d) W. J. Hehre, R. Ditchfield, J. A. Pople, J. Chem. Phys., 1972, 56, 2257-2261.

43 J. P. Pedrew, K. Bulke and M. Ernzerhof, Phys. Rev. Lett., 1996, 77, 3865-3868.

44 S. Grimme, J. Comput. Chem., 2006, 27, 1787-1789.

45 A. Klamt, G. Schüürmann, J. Chem. Soc. Perkin Trans. 2, 1993, 799-805.

46 (a) F. Jensen, in Introduction to Computational Chemistry, $2^{\text {nd }}$ Ed., Wiley, Chichester, 2007; (b) C. J. Cramer, in Essentials of Computational Chemistry $2^{\text {nd }}$ Ed., Wiley, Chichester, 2004. 
